\title{
Concomitant bovine viral diarrhea, mycotoxicosis, and seneciosis in beef cattle from northern Paraná, Brazil
}

\author{
Ocorrência simultânea de diarreia viral bovina, micotoxicose e \\ seneciose em bovinos de corte da região norte do Paraná, Brasil
}

\author{
Selwyn Arlington Headley ${ }^{1 *}$; Amauri Alcindo Alfieri ${ }^{1}$; \\ Juliana Torres Tomazi Fritzen²; Gustavo Rodrigues Queiroz²; \\ Júlio Augusto Naylor Lisbôa ${ }^{3}$; Daisy Pontes Netto ${ }^{1}$; Werner Okano ${ }^{4}$; \\ Karina Keller Marques Costa Flaiban ${ }^{1}$; Alice Fernandes Alfieri ${ }^{1}$
}

\begin{abstract}
This study investigated the causes of mortality in cattle from northern Paraná, southern Brazil, during which 9.5\% (23/242) of Nellore cows died after clinical manifestations of uncoordinated gait, fever, transient bloody diarrhea, dyspnea, and lateral decumbency. All cows were maintained on poor pastures, and ingested moldy silage and sprouts of Senecio brasiliensis. Serum samples $(n=17)$ were collected for virus neutralizing (VN) antibodies assays against bovine viral diarrhea virus (BVDV) and bovine herpesvirus 1 (BoHV-1). Three cows were necropsied; fragment of tissue samples collected during necropsy from two cows were used in polymerase chain reaction (PCR) and reverse transcriptionPCR assays to identify BoHV-1 and BVDV; blood samples $(n=6)$ were obtained for hematological and biochemical analyses. Significant gross findings of all cows included increased liver consistency, intestinal bleeding, and pulmonary hemorrhage. Histopathology revealed hepatic fibrosis, hemorrhagic enteritis, renal tubular necrosis, pulmonary hemorrhage, and widespread vasculitis. All serum samples contained VN antibodies against BoHV-1, but only four of these reacted positively to BVDV. The RTPCR assays amplified specific amplicons of the untranslated region of BVDV from tissues samples of both animals; direct sequencing and sequence analyses demonstrated that these sequences clustered within the BVDV subgenotype 1d; all PCRs were negative for BoHV-1. Toxicological analyses of the moldy silage demonstrated elevated concentrations of ochratoxin $(75.94 \mu \mathrm{g} / \mathrm{kg})$. Laboratory evaluations revealed renal and hepatic dysfunctions. These findings confirmed the combined actions of BVDV-1d infection and toxicosis by mycotoxin and S. brasiliensis in cattle mortality at this farm.
\end{abstract}

Key words: Bovine diseases, multifactorial conditions, beef cattle, Senecio brasiliensis, ochratoxicosis

\section{Resumo}

O objetivo desse estudo foi avaliar a causa de mortalidade observada em um rebanho bovino constituído por vacas da raça Nelore criadas no norte do Estado do Paraná, região sul do Brasil, no qual 9,5\% (23/242) das vacas morreram após manifestação clínica de andar cambaleante, febre, diarreia transitória

\footnotetext{
${ }^{1}$ Profs. Drs., Dept ${ }^{\circ}$ de Medicina Veterinária Preventiva, Universidade Estadual de Londrina, UEL, Londrina, PR, Brasil. E-mail: selwyn.headley@uel.br; alfieri@uel.br; rnetto@uel.br; kkflaiban@uel.br; aalfieri@uel.br

${ }^{2}$ Discentes do Curso de Pós-Graduação em Ciência Animal, UEL, Londrina, PR, Brasil. E-mail: jufritzen@uel.br; gustavorodriguesqueiroz11@gmail.com

${ }^{3}$ Prof. Dr., Dept ${ }^{\circ}$ de Clínicas Veterinárias, UEL, Londrina, PR, Brasil. E-mail: janlisboa@uel.br

${ }^{4}$ Prof. Dr., Universidade Norte do Paraná, UNOPAR, Arapongas, PR, Brasil. E-mail: vetwerner@gmail.com

* Author for correspondence
} 
com sangue, dispneia e decúbito lateral. O rebanho era mantido em pastagens degradadas e ingeriram silagem de milho mofada e broto de Senecio brasiliensis. Amostras de soro $(n=17)$ foram coletadas para a detecção de anticorpos neutralizantes para o vírus da diarreia viral bovina (BVDV) e herpesvírus bovino 1 (BoHV-1). Três vacas foram necropsiadas e os fragmentos de tecidos foram avaliados por RT-PCR e PCR para a identificação de BVDV e BoHV-1, respectivamente. Os achados macroscópicos incluíram aumento da consistência hepática, sangramento intestinal e hemorragia pulmonar. A histopatologia revelou fibrose hepática, enterite hemorrágica, necrose tubular renal e vasculite generalizada. Todas as amostras de soro apresentaram anticorpos neutralizantes para o BoHV-1 e quatro amostras foram positivas para o BVDV. A RT-PCR amplificou produtos da região não-traduzida do genoma do BVDV a partir de tecidos de ambos os animais. Análises filogenéticas dos produtos amplificados demonstraram que as sequências agruparam com o BVDV subgenotipo 1d. Todas as amostras analisadas por PCR para a identificação do DNA do BoHV-1 foram negativas. Avaliações da bioquímica sérica revelaram disfunções renal e hepática. Análises toxicológicas nas amostras de silagem milho mofada apresentaram altas concentrações de ocratoxina $(75,94 \mu \mathrm{g} / \mathrm{kg})$. Esses resultados confirmam que as ações combinadas da infecção com o BVDV-1d, a micotoxicose e a intoxicação por S. brasiliensis contribuíram com a mortalidade de vacas no rebanho avaliado.

Palavras-chave: Doenças de bovinos, doenças multifatoriais, gado de corte, Senecio brasiliensis, ocratoxicose

\section{Introduction}

Bovine viral diarrhea virus (BVDV) is an RNA virus of the Pestivirus genus within the family Flaviviridae (KING et al., 2011). BVDV is one of the most important pathogens of cattle, occurs worldwide, and results in severe economic losses to the cattle industry (HOUE, 1999; BROWN et al., 2007). This virus is divided into two major species (BVDV-1 and -2), with two distinct biotypes (cytopathic, CP; and non-cytopathic, $\mathrm{NCP}$ ) occurring within these species (BROWN et al., 2007; MACLACHLAN; DUBOVI, 2011). In Brazil, outbreaks of bovine viral diarrhea (BVD) occur predominantly due to BVDV-1, NCP biotype, with few descriptions of this disease being related to type 2 (CORTEZ et al., 2006; LUNARDI et al., 2008).

Mycotoxins are secondary metabolites produced by fungi that grow on a wide variety of feedstuffs and food consumed by domestic animals and humans (OSWALD et al., 2005; UPADHAYA et al., 2010). The most important mycotoxins of interest to food production are aflatoxin, ochratoxin, and fumonisin (OSWALD et al., 2005; MOSTROM; JACOBSEN, 2011). However, intoxication is more frequently associated with peracute, acute, or chronic aflatoxicosis (OSWALD et al., 2005;
GALEY, 2009). Clinical manifestations of peracute toxicosis include hemorrhage, bloody diarrhea, and acute death (GALEY, 2009). Chronic aflatoxicosis predispose susceptible ruminants to infectious diseases (OSWALD et al., 2005; GALEY, 2009; UPADHAYA et al., 2010), due to impaired secretory functions and viability of neutrophils and macrophages (OSWALD et al., 2005). Affected animals can demonstrate reduced growth rate, decreased feed efficiency, rough hair coat, and hepatic fibrosis with regeneration (GALEY, 2009). Ochratoxicosis produces similar manifestations in livestock, particularly pigs (GALEY, 2009), but ochratoxicosis is rarely diagnosed in cattle due to efficient ruminal degradation (BATTACONE et al., 2010).

Chronic seneciosis affecting cattle in Brazil is caused predominantly by the hepatotoxic plant, Senecio brasiliensis (TOKARNIA et al., 2002). Further, plants of the genus Senecio are responsible for more than $50 \%$ of cattle mortality due to toxic plants, with an annual estimated economic loss of 12.8 - 18 million USD to the Brazilian cattle industry (RIET-CORREA; MEDEIROS, 2001). Most outbreaks of chronic seneciosis in cattle have been described in animals maintained in inadequate pastures containing Senecio spp. (RIET-CORREA; 
MEDEIROS, 2001; TOKARNIA et al., 2002). Intoxication is due to the presence of pyrrolizidine alkaloids contained within the plant that inhibits DNA synthesis and mitosis of hepatocytes resulting in megalocytosis (STALKER; HAYES, 2007). In chronic Senecio-induced poisoning, the liver frequently becomes atrophic due to the rapid loss of hepatocytes that surpasses the rate of regeneration (STALKER; HAYES, 2007). Characteristic histopathological alterations of chronic seneciosis include megalocytosis (STALKER; HAYES, 2007), portal and/or bridging fibrosis with proliferation of bile duct epithelium cells within the portal triads (TOKARNIA et al., 2002; HEADLEY et al., 2004; STALKER; HAYES, 2007).

Descriptions of coinfections affecting cattle include bovine leukemia virus and Mycobacterium bovis in the USA (SLEDGE et al., 2009), Sarcocystis cruzi, Neospora caninum, and Toxoplasma gondii in Argentina (MORE et al., 2008), and BVDV with multiple respiratory diseases in Canada (RICHER et al., 1988). Coinfections in cattle have been described involving N. caninum, Hammondia sp., and T. gondii in north-eastern Brazil (SANTOS et al., 2010); bovine herpesvirus 1 (BoHV-1) and -5 (CAMPOS et al., 2009), and BoHV-5 and BVDV in southern Brazil (SPILKI et al., 2006); and concomitant BoHV-1, BVDV with enzootic bovine leucosis in Midwest Brazil (ALEXANDRINO et al., 2011). There is also the description of simultaneous chronic seneciosis and eurytrematosis in southern Brazil (HEADLEY et al., 2004), and concomitant infections due to Histophilus somni, BoHV-1, BVDV, N. caninum, and Brucella abortus in fetuses from different geographical regions of Brazil (HEADLEY et al., 2014). However, descriptions of the concurrent occurrence of BVD, seneciosis, and mycotoxicosis affecting cattle were not found when major databases were examined. This report presents the findings associated with cattle mortality due to concomitant BVD, mycotoxicosis, and chronic seneciosis.

\section{Materials and Methods}

Animals and clinical history

During mid-July to late September, 2011, twentythree, 4-6 years-old, Nellore cows from a herd of 242, maintained in a farm located approximately $50 \mathrm{~km}$ from Londrina, southern Brazil, died. The consulting veterinarian indicated that the first death occurred in mid-July; thereafter five animals died within two weeks after the first cow was found dead. He related that most affected animals demonstrated uncoordinated gait, fever, transient bloody diarrhea, dyspnea, and lateral decumbency terminating in spontaneous death within 48-72 $\mathrm{h}$ after the onset of clinical signs. By the end of August, another six cows died with similar manifestations. Therapeutic interventions were unsuccessful, and the attending veterinary suspected aflatoxin poisoning.

An onsite visit to the farm in early September revealed that all cows were maintained in fenced pickets with poor pasture that contained sprouts of eaten S. brasiliensis; the pasture consisted of a mixture of Bahia (Paspalum notatum), palisade (Brachiaria brizantha), and Guinea grass (Panicum maximum). The farm administrator indicated that the cows received daily rations that contained corn-derived silage, fallen humid corn stalks, and commercial mineral supplement, fed in open troughs; potable water was provided ad libitum from an artesian well. He further indicated that the animals were immunized against foot-and-mouth disease, brucellosis, and clostridiosis. Inspection of the silage administered to and consumed by the cows at the time of visit, revealed several moldy areas within the feeding trough. By late-September an additional 11 cows that reportedly demonstrated similar clinical manifestations died. The moldy silage was withdrawn, the food regime has been altered, and all remaining animals were immunized against BoHV1, BVDV, bovine parainfluenza, bovine respiratory syncytial virus, and leptospirosis, with a booster 30 days thereafter. Deaths have since ceased at the farm and the remaining cows were re-vaccinated. 


\section{Hematological and toxicological analyses}

Blood samples without EDTA were randomly collected from 17 animals for virus neutralization assays to detect antibodies of BVDV and BoHV-1. During another visit, blood samples from six cows were used for the hematological and biochemical analyses; one of these was euthanized in extremis (animal \# 1), while another (\#2) died spontaneously two days after being clinically evaluated. Samples of the moldy silage were collected and submitted for the identification of mycotoxins.

\section{Virus neutralization for BoHV-1 and $\mathrm{BVDV}$}

Virus neutralization (VN) for BoHV-1 and BVDV was done from sera obtained from 17 cows. VN for BoHV-1 (Los Angeles strain) was performed by using serial 2-fold dilutions of sera made in minimum essential medium as described (MÉDICI et al., 2000); sera were tested for virus neutralizing antibodies through the $1: 1,024$ dilutions. $\mathrm{VN}$ for BVDV-1 (Singer strain) was done as described (DIAS et al., 2010), using 2-fold dilutions starting at 1:5 through 1:160. Sera were considered positive when cytopathic effect was observed at titers that were $\geq 2$ for BoHV-1 and $\geq 10$ for BVDV.

\section{DNA extraction, PCR/RT-PCR assays, and sequencing}

DNA and/or RNA was extracted from freshly collected tissue fragments (intestine, kidney, liver, and lungs), by using Proteinase K (Ambion, Grand Island, NY, USA) associated with the phenol/ chloroform/isoamyl alcohol and silica/guanidine isothiocyanate method (ALFIERI et al., 2006). The RT-PCR assay consisted of a protocol using the primer pairs $324 / 326$ designed to amplify the $288 \mathrm{bp}$ amplicons of the 5'-untranslated region (5'-UTR) of pestivirus (VILČEK et al., 1994). The PCR assay targeted the glycoprotein C gene of BoHV-1 as described (CLAUS et al., 2005). Positive controls consisted of DNA and RNA cell culture (MDBK) adapted Los Angeles strain of BoHV-1 and the NADL strain of BVDV. Nucleasefree water (Invitrogen Corporation, Carlsbad, CA, USA) was used as negative controls. All PCR/RTPCR products were separated by electrophoresis in $2 \%$ agarose gels, stained with ethidium bromide, and examined under ultraviolet light.

The amplified RT-PCR products were then purified (illustra GFX PCR DNA and Gel Band Purification Kit, GE Healthcare, Little Chalfont, Buckinghamshire, UK) and submitted for direct sequencing using the forward and reverse primers. The partial nucleotide sequences were initially compared by the BLAST program (http://www. ncbi.nlm.nih.gov/BLAST) with similar sequences deposited in GenBank. Phylogenetic tree and sequence alignments based on selected members of BVDV-1 were then created by using MEGA 5.10 (TAMURA et al., 2011) constructed by the neighborjoining method, based on 1,000 bootstrapped data sets; distances values were calculated by using the Kimura 2 parameter model. Members of BVDV-2 type were used as the out-group to provide stability to the generated tree.

\section{Necropsy and histopathology}

Two cows that died spontaneously and one euthanized, in extremis, were necropsied soon after death; tissue fragments (brain, liver, lungs, intestine, abomasum, rumen, kidneys, and lymph nodes) were fixed by immersion in $10 \%$ buffered formalin solution and routinely processed for histopathological evaluation. Selected tissue fragments (brain, intestine, kidneys, liver, and lungs) from two cows (\# 2 and 3) were aseptically collected and maintained frozen at $-20^{\circ} \mathrm{C}$ until used for molecular diagnostics.

For comparative analysis, the intensity of the principal histopathological alterations observed in each animal were subjectively graded (HEADLEY et al., 2012), as absent, 0; discrete, +; moderate ++ , and severe +++ . 


\section{Results}

\section{Animals and clinical history}

The principal clinical manifestations of the three animals necropsied during this investigation are given in Table 1; these were more pronounced in cow \# 1. Diarrhea (bloody and/or fetid), reduced body weight, and sternal decumbency were observed in all animals, while two of these demonstrated uncoordinated gait and ruminal hypomotility; the severely affected cow was also depressed with generalized muscular weakness, moderate dehydration, hind limb paresis, and was euthanized in extremis; the other two died spontaneously.

Table 1. The clinical manifestations, gross alterations, and outcome of Nellore cows during this investigation.

\begin{tabular}{|c|c|c|c|c|}
\hline Animal & Signalment & $\begin{array}{c}\text { Principal clinical } \\
\text { manifestations }\end{array}$ & Significant gross alterations & Outcome \\
\hline 1 & Female, 5 yrs & $\begin{array}{l}\text { Depression } \\
\text { Fetid diarrhea } \\
\text { Generalized muscular weakness } \\
\text { Hind limb paresis } \\
\text { Hypothermia } \\
\text { Moderate dehydration }(8 \%) \\
\text { Reduced body weight } \\
\text { Ruminal hypomotility } \\
\text { Sternal decumbency } \\
\text { Tachycardia }\end{array}$ & $\begin{array}{l}\text { Abomasal ulcers } \\
\text { Discrete increase in liver consistency } \\
\text { Hydroperitoneum } \\
\text { Intestinal bleeding } \\
\text { Renal cortical congestion }\end{array}$ & Euthanasia \\
\hline 2 & Female, 4 yrs & $\begin{array}{l}\text { Bloody diarrhea } \\
\text { Reduced body weight } \\
\text { Ruminal hypomotility } \\
\text { Sternal decumbency } \\
\text { Uncoordinated gait }\end{array}$ & $\begin{array}{l}\text { Abomasal hemorrhage } \\
\text { Congested meningeal vessels } \\
\text { Discrete increase in liver consistency } \\
\text { Intestinal bleeding } \\
\text { Lymphadenopathy } \\
\text { Pulmonary hemorrhage }\end{array}$ & $\begin{array}{l}\text { Spontaneous } \\
\text { death }\end{array}$ \\
\hline 3 & Female, 6 yrs & $\begin{array}{l}\text { Bloody diarrhea } \\
\text { Reduced body weight } \\
\text { Sternal decumbency } \\
\text { Uncoordinated gait }\end{array}$ & $\begin{array}{l}\text { Hydroperitoneum } \\
\text { Intestinal hemorrhage } \\
\text { Severe increase in liver consistency }\end{array}$ & $\begin{array}{l}\text { Spontaneous } \\
\text { death }\end{array}$ \\
\hline
\end{tabular}

Source: Elaborated by the authors.

\section{Clinical laboratory findings}

The laboratory findings of the six cows are resumed in Table 2. Most animals (83.3\%; 5/6) demonstrated neutrophilic leucocytosis; lymphopenia was observed in two of these. Hypoalbuminemia occurred in all animals, but only cow \# 1 had azotemia and severe elevation of hepatic enzymatic activity. Three cows demonstrated at least six-fold increase in serum alkaline phosphatase activity (AP) levels, with enzymatic activity being more elevated in cows \# 1 (676 UI/L) and 4 (765 UI/L); only cow \# 7 had serum AP levels within physiological limits. Two of these cows died after the laboratory results were available; cow \# 1 was euthanized in extremis, and cow \#4 died spontaneously but was not submitted for necropsy. The remaining four animals have since recuperated. Toxicological analyses, done by using Thin Layer Chromatography of the moldy silage, revealed $75.94 \mu \mathrm{g} / \mathrm{kg}$ of ochratoxin and 8.27 $\mu \mathrm{g} / \mathrm{kg}$ of aflatoxin $\mathrm{G} 2$. 
Table 2. Hematological and biochemical findings of cows with chronic hepatic disease and bovine viral diarrhea virus infection.

\begin{tabular}{|c|c|c|c|c|c|c|c|}
\hline $\begin{array}{l}\text { Laboratory } \\
\text { Parameters }\end{array}$ & $\begin{array}{l}\text { Reference } \\
\text { values }\end{array}$ & Cow 1 & Cow 4 & Cow 5 & Cow 6 & Cow 7 & Cow 8 \\
\hline \multicolumn{8}{|l|}{ Hemogram } \\
\hline Packed Cell Volume (\%) & $27-48$ & 40.1 & 39.7 & 25.9 & 31 & 32.4 & 27.8 \\
\hline Red blood cells $\left(\times 10^{6} / \mu \mathrm{L}\right)$ & $6-11.6$ & 7.67 & 6.81 & 4.07 & 5.3 & 5.52 & 4.68 \\
\hline Hemoglobin $(\mathrm{g} / \mathrm{dL})$ & $8.50-16.5$ & 14.5 & 12.8 & 8.2 & 9.9 & 10.4 & 8.9 \\
\hline Total plasma protein $(\mathrm{g} / \mathrm{dL})$ & $6.6-7.8$ & 4 & 4.2 & 8 & 6.8 & 7 & 7.6 \\
\hline Leucocytes $\left(\mathrm{x} 10^{3} / \mu \mathrm{L}\right)$ & $6,200-12,200$ & 20,730 & 19,600 & 14,050 & 15,480 & 14,850 & 11,810 \\
\hline Lymphocytes $\left(\mathrm{x} 10^{3} / \mu \mathrm{L}\right)$ & $3,300-8,000$ & $2,694.9$ & 3,724 & $4,636.5$ & $3,715.2$ & 2,970 & $6,731.7$ \\
\hline Eosinophils $\left(\mathrm{x} 10^{3} / \mu \mathrm{L}\right)$ & $0-2,400$ & ---- & --- & --- & 154.8 & 742.5 & 944.8 \\
\hline Segmented neutrophils $\left(\mathrm{x} 10^{3} / \mu \mathrm{L}\right)$ & $1,300-3,400$ & $18,031.1$ & 15,876 & $9,413.5$ & 11,610 & $11,137.5$ & $4,133.5$ \\
\hline MCV (fL) & $30.5-55.5$ & 52.4 & 58.3 & 63.8 & 58.6 & 58.7 & 59.5 \\
\hline $\mathrm{MCHC}(\mathrm{g} / \mathrm{dL})$ & $28-38$ & 36.1 & 32.2 & 31.6 & 31.9 & 32 & 32 \\
\hline $\mathrm{MCH}(p g)$ & $9.7-19$ & 18.9 & 18.7 & 20.1 & 18.6 & 18.8 & 19 \\
\hline \multicolumn{8}{|l|}{ Serum chemistry } \\
\hline Albumin & $2.7-4.3$ & 1.2 & 1.3 & 1.7 & 2 & 2.2 & 2.1 \\
\hline Creatinine (mg/dL) & $1-2.7$ & 4.18 & 1.28 & 0.9 & 1.23 & 1.04 & 1.19 \\
\hline Urea (mg/dL) & $5.8-35.9$ & 117 & 41 & 25 & 25 & 21 & 26 \\
\hline CK (UI/L) & $35-280$ & 4,730 & 165 & 105 & 114 & 114 & 77 \\
\hline AST (UI/L) & $32-71$ & 940 & 126 & 71 & 131 & 77 & 96 \\
\hline GGT (UI/L) & $3.7-31.3$ & 16 & 10 & 40 & 139 & 20 & 26 \\
\hline AP (UI/L) & $33-100$ & 676 & 597 & 244 & 765 & 36.5 & 389 \\
\hline Total bilirubin $(\mathrm{mg} / \mathrm{dL})$ & $0.32-0.74$ & 0.36 & 0.19 & 0.12 & 0.26 & 0.25 & 0.11 \\
\hline Conjugated bilirubin (mg/dL) & $0.01-0.34$ & 0.24 & 0.13 & 0.08 & 0.18 & 0.17 & 0.07 \\
\hline Unconjugated bilirubin $(\mathrm{mg} / \mathrm{dL})$ & $0.16-0.67$ & 0.12 & 0.06 & 0.04 & 0.08 & 0.08 & 0.04 \\
\hline
\end{tabular}

Legend: CK, Creatine kinase; AST, Aspartate aminotransferase; GGT, Gama-glutamyltransferase; AP, Alkaline phosphatase.

Source: Elaborated by the authors.

\section{BoHV-1 and BVDV virus neutralization assays}

Antibodies against BoHV-1 were detected in all 17 animals evaluated; these cows demonstrated elevated virus neutralizing (VN) antibody titers that varied between 32 to $\geq 1,024$. BoHV-1-neutralizing antibody titers of 128 were the most predominant, and occurred in $35.3 \%(6 / 17)$ of these cows. Reduced BVDV-neutralizing antibody titers were demonstrated in the few animals $(23.5 \% ; 4 / 17)$ that were positive. However, all cows with BVDVneutralizing antibodies were also positive by $\mathrm{VN}$ for BoHV-1.

\section{Molecular characterization}

Amplicons of $288 \mathrm{bp}$ were amplified from the RTPCR assay designed to identify the 5'-UTR region of Pestivirus from tissue samples of both cows; the BoHV-1 PCR assay was negative for all tissues evaluated. Initial BLAST analysis demonstrated that these sequences (UEL6-BR/11, GenBank accession \# KC562901; UEL7-BR/11, GenBank accession \# KC562902) revealed 92-99\% similarity with other BVDV-1 species sequences deposited in GenBank. However, phylogenetic analyses (Figure 1) demonstrated that these sequences clustered with 
other BVDV-1d sequences, including that (UEL5BR/09, GenBank accession \# JQ513585) of a recent investigation by our group identified in cattle from a distinct geographical location of southern Brazil
(OTONEL et al., 2014). The GenBank accessions numbers of the BVDV strains/isolates used for phylogenetic analyses during this study are given in Figure 1.

Figure 1. The phylogenetic relationship of nucleotide sequences of selected bovine viral diarrhea virus (BVDV) strains based on the 5'-UTR region of Pestivirus RNA. The tree was generated by MEGA 5.10; the name of the strain/ isolate and the associated GenBank accession number (in parentheses) of the sequences used are given. The sequences derived from this study are highlighted within the boxes. Selected strains of BVDV-2 type were used as the out-group.

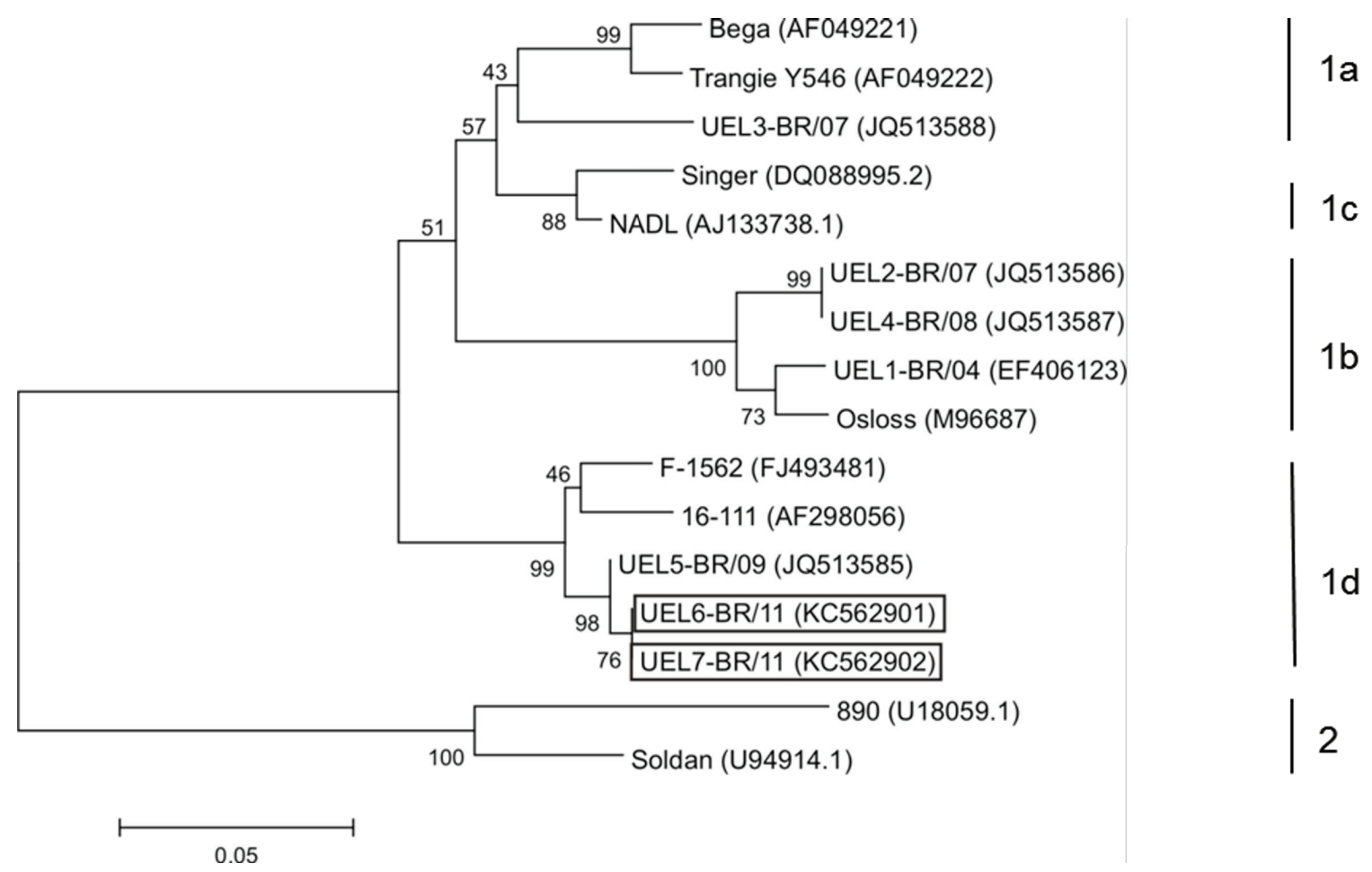

Source: Elaborated by the authors.

\section{Pathological findings}

The principal gross alterations observed in the three cows were restricted to the gastrointestinal tract and the liver, and are resumed in Table 3. All cows demonstrated intestinal bleeding with destruction of Peyer's patches, but the entire extension of the mucosa of the gastrointestinal tract (duodenum through rectum) was severely hemorrhagic in cow \# 2. The cow with severe intestinal bleeding also demonstrated marked lymphadenopathy, affecting predominantly the cervical, subscapular, inguinal, and mesenteric lymph nodes. Severe hepatic manifestation of disease was observed in cow \# 2 , and was characterized by marked increase in the consistency of the organ; this was discrete in the other two cows. Moderate hydroperitoneum (approximately 1.5 - 2 1) occurred in two cows; one with elevated activity of hepatic enzymes (\#1) and the other (\#3) that demonstrated severe hepatic fibrosis. 
Table 3. Principal histopathological alterations observed in cattle during this investigation.

\begin{tabular}{|c|c|c|c|}
\hline \multirow{2}{*}{ Principal histopathological findings } & \multicolumn{3}{|c|}{ Animals } \\
\hline & 1 & 2 & 3 \\
\hline \multicolumn{4}{|l|}{ Liver } \\
\hline Biliary stasis & + & + & +++ \\
\hline Megalocytosis & + & + & ++ \\
\hline Nodular regeneration & 0 & ++ & +++ \\
\hline Portal and bridging fibrosis & + & ++ & +++ \\
\hline \multicolumn{4}{|l|}{ Intestine } \\
\hline Cryptal dilation and necrosis & +++ & +++ & ++ \\
\hline Hemorrhage & ++ & ++ & + \\
\hline Villous fusion and atrophy & ++ & ++ & + \\
\hline \multicolumn{4}{|l|}{ Brain } \\
\hline Spongy degeneration & + & + & ++ \\
\hline Vasculitis & ++ & 0 & 0 \\
\hline \multicolumn{4}{|l|}{ Kidney } \\
\hline Tubular necrosis & +++ & + & ++ \\
\hline Vasculitis & +++ & 0 & + \\
\hline
\end{tabular}

Legend: 0 , absent; +, discrete; ++, moderate; +++, severe.

Source: Elaborated by the authors.

Significant histopathological lesions were dilation and necrosis, villous atrophy and fusion, observed predominantly within the liver and depletion of intestinal lymphoid tissue, and gastrointestinal tract, and to some extent within discrete to moderate hemorrhage predominantly the brain and kidneys of all cows necropsied. within the intestinal mucosa of all animals. Hepatic lesions were observed in all animals, Dilated intestinal crypts were lined by cuboidal but were more severe in cow \# 3. In this animal, epithelial cells and contained necrotic debris and there was severe fibrosis (bridging and portal) and nodular regeneration that resulted in small islands of existing atrophic hepatocytes (Figure 2A). Proliferation of bile duct epithelium at the portal traits and biliary stasis within bile canaliculi and ducts (Figure 2B) occurred in the liver of all cows, but was predominant in cow \# 3; megalocytosis occurred in all cows but was discrete in two and moderate in in one animal (\# 3). Intestinal lesions were observed in all cows but were more severe in two of these; being characterized by crypt mucus (Figure 2C-D); vasculitis was prominent within the submucosa of cows \# 1 and 2. There was spongy degeneration (status spongiosus) of the cerebellar and cerebral white matter of all cows, but necrotizing vasculitis of the brain was only observed in cow \# 2. Necrotizing vasculitis and tubular necrosis were predominant within the kidney of cow \# 1, but was also observed in the other cows. Other significant pathological observations included pulmonary hemorrhage and purulent bronchopneumonia. 
Figure 2. Histopathological findings in cattle with chronic seneciosis and infected by bovine viral diarrhea virus. There is severe hepatic fibrosis resulting in the loss of hepatocytes (A), proliferation of bile duct epithelial cells with biliary stasis (open arrows), and megalocytosis (closed arrow) at the portal triad of the liver (B). Observe the fused intestinal villi and dilated crypts of the small intestine (C-D). Hematoxylin and eosin stain; Bar, A and C $100 \mu \mathrm{m} ; \mathrm{B}$

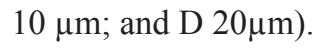

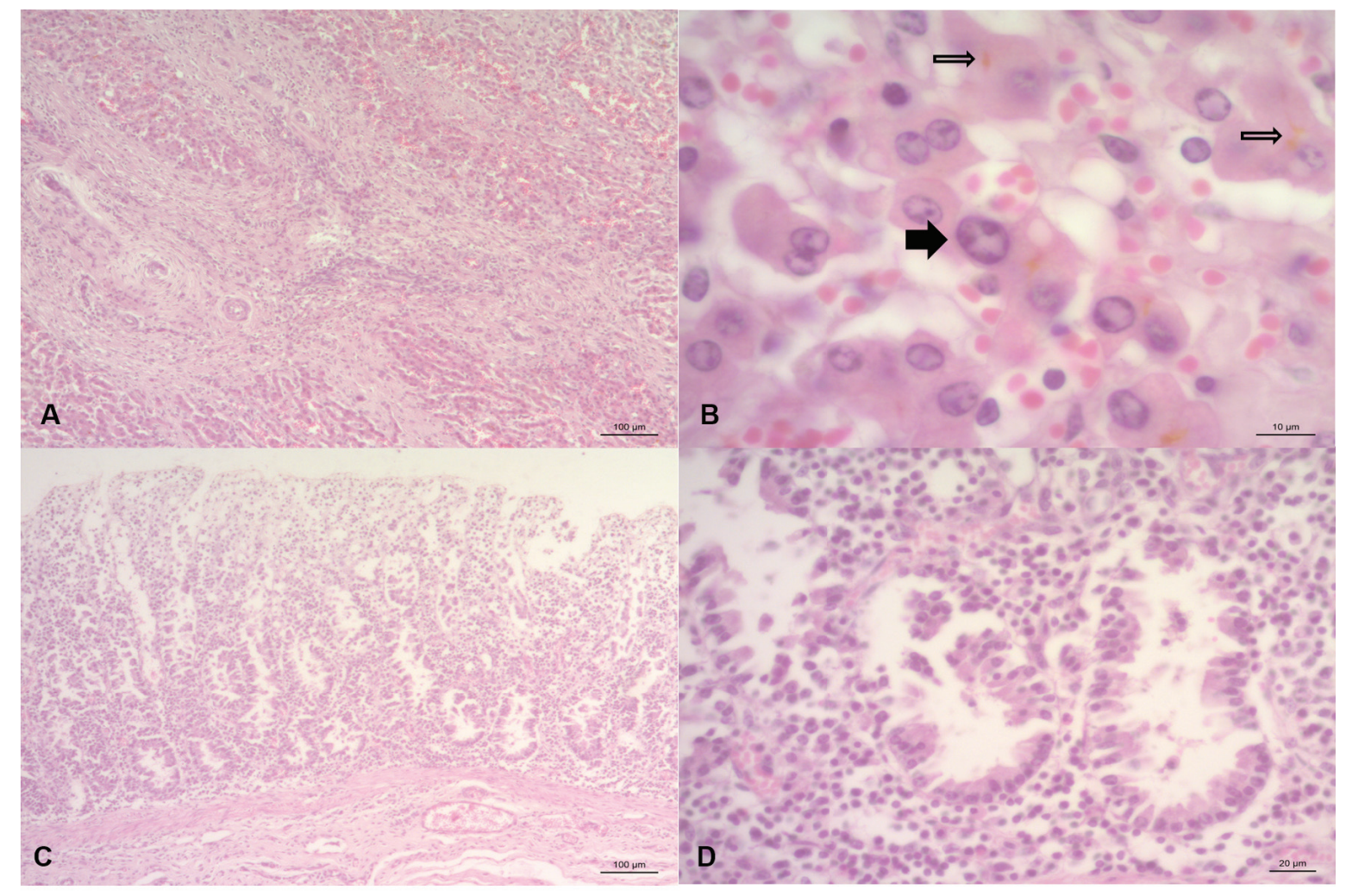

Source: Elaborated by the authors.

\section{Discussion}

The results of this investigation have demonstrated that cattle mortality $(9.5 \% ; 23 / 242)$ at this farm was due to the simultaneous effects of been maintained on inadequate pasture, acute BVDV-induced infection, associated with poisoning due to the ingestion of moldy corn (contaminated with ochratoxin) and $S$. brasiliensis. The clinical manifestations described during this investigation have been partially associated with poisoning due to mycotoxin in livestock (UPADHAYA et al., 2010; MOSTROM; JACOBSEN, 2011) and infection due to BVDV (LUNARDI et al., 2008; MACLACHLAN; DUBOVI, 2011). The pathological findings observed within the liver and brain (hepatic encephalopathy) of the affected cows are consistent with those described in cases of chronic seneciosis (TOKARNIA et al., 2002; HEADLEY et al., 2004; STALKER; HAYES, 2007), while the intestinal lesions are highly suggestive of BVDV-induced hemorrhagic enteritis (BROWN et al., 2007; LUNARDI et al., 2008). Additionally, molecular diagnostics identified BVDV RNA within the tissues of cows that demonstrated lesions that are characteristic of BVD, while toxicological analyses demonstrated that the moldy silage contained elevated levels of ochratoxin. The authors believe that the scarcity of adequate pasture at the farm resulted in reduced body score, which forced the cows to ingest the unpalatable hepatotoxic plant and the moldy silage resulting in chronic hepatic dysfunction and renal disease. The 
immunosuppressive effects of acute BVD infection produced additional damage to the already impaired immunological system of the affected cows, which facilitated the maintenance of BoHV-1 within the herd and the development of the pulmonary disease (necrosis and bronchopneumonia) observed in some of these cows. To the best of the authors' knowledge, these findings represent the first description of cattle mortality associated with the combined effects of inadequate pasture, acute BVDV infection, nephrotoxic mycotoxicosis coupled with chronic seneciosis.

The elevated titers of antibodies against BoHV-1 observed by VN suggest that the cattle maintained in this farm were in contact with this virus, i.e., viral clearance, and might explain the negative results observed with the BoHV-1 PCR assay. Alternatively, the reduced levels of BVDV neutralizing antibodies coupled with the positive RT-PCR findings and pathological alterations are indicative of acute BVD infection (LUNARDI et al., 2008); widespread vasculitis as occurred during this study is frequently observed in BVD (BROWN et al., 2007; MACLACHLAN; DUBOVI, 2011). Additionally, the negative BVDV VN suggests that those animals were not in contact with the virus and are highly susceptible to infection. Concomitant infections of BVDV have also occurred with BoHV-5 (SPILKI et al., 2006), Mannheimia haemolytica and Mycoplasma species (HANAA et al., 2010), BoHV-1 and enzootic bovine leukemia virus (ALEXANDRINO et al., 2011), BoHV-1 and bovine respiratory syncytial virus (RICHER et al., 1988), and H. somni, B. abortus, N. caninum (HEADLEY et al., 2014). These results demonstrate the immunosuppressive capacity of BVDV, which impairs the lymphocytic memory response for other pathogens (ALEXANDRINO et al., 2011), thereby facilitating the development of associated disease.

The molecular findings and characteristic histopathological alterations effectively confirmed the participation of BVDV-1d in the etiopathogenesis of the clinical and pathological manifestations observed in these animals. BVDV-1d was recently associated with reproductive disease in cattle from southern Brazil (OTONEL et al., 2014), where three different BVDV subgenotypes (BVDV-1a, BVDV$1 \mathrm{~b}$, and BVDV-1d) were identified in a single herd. Collectively, these findings might represent the first descriptions of BVDV subgenotype 1d within Brazilian cattle herds. Alternatively, diseases due to the occurrence of BVDV subgenotypes 1a, 1b, and $2 \mathrm{a}$ are more predominant within Brazil (FLORES et al., 2005; CORTEZ et al., 2006), with description of the $1 \mathrm{~b}$ subgenotype been associated with acute BVD characterized by erosive lesions within the gastrointestinal tract (LUNARDI et al., 2008). These findings suggest that BVDV is disseminated within cattle herds from Brazil and new subgenotypes are likely to be diagnosed as the virus evolves.

Of significant importance during this investigation was the finding of elevated levels of ochratoxin within the moldy corn silage that was been fed constantly to the affected cattle. This resulted in the renal lesions observed in the necropsied animals and the enzymatic alterations demonstrated in cow \# 1. Ruminants are considered more resistant to poisoning due to mycotoxins than monogastrics (GALEY, 2009; MOSTROM; JACOBSEN, 2011); while mycotoxicosis is related to the age, breed, sex, toxic dose ingested, and the immunological state of the affected animal (UPADHAYA et al., 2010). Additionally, chronic mycotoxicosis is known to alter the immunological system of affected animals and increase their susceptibility to infectious disease (MOSTROM; JACOBSEN, 2011), which might explain the concomitant acute BVD infection diagnosed and the BoHV-1 circulating within this herd. Moreover, ochratoxicosis is more frequently associated with mortality in poultry and pigs (GALEY, 2009; UPADHAYA et al., 2010), with manifestation of disease being rare in cattle due to the efficiency of ruminal transformation when small quantities are ingested (BATTACONE et al., 2010). However, the level of contamination by ochratoxin $(75.94 \mu \mathrm{g} /$ 
$\mathrm{kg}$ ) identified within the moldy corn silage, greatly exceeds the maximum recommended daily intake levels $(25 \mu \mathrm{g} / \mathrm{kg}$ ) for ruminants (GALEY, 2009; MOSTROM; JACOBSEN, 2011), and induced renal toxicosis in the animals evaluated. The effects of environmental conditions as contributory factors to cattle mortality during this investigation cannot be overlooked, since the incident occurred during the winter of southern Brazil, which favors the development of mycotoxins (UPADHAYA et al., 2010; MOSTROM; JACOBSEN, 2011). Additionally, these findings might represent the first characterization of chronic ochratoxicosis in cattle.

The severely fibrotic liver associated with megalocytosis, proliferation of bile duct epithelial cells, and biliary stasis are hallmarks of Senecio spp. poisoning (TOKARNIA et al., 2002; STALKER; HAYES, 2007), and could have contributed to the elevated levels of aspartate aminotransferase activity and total bilirubin with concomitant hypoalbuminemia observed during this investigation. Although seneciosis is one of the major causes of the mortality of adult cattle in Brazil resulting in elevated economic losses (RIETCORREA; MEDEIROS, 2001; TOKARNIA et al., 2002)TOKARNIA; DOBEREINER; PEIXOTO, 2002), most outbreaks have described these cases without a concomitant disease. However, there is an association of chronic seneciosis with infestation due to the pancreatic fluke (HEADLEY et al., 2004). Nevertheless, most cases of cattle intoxication by poisonous plants in Brazil occurs during the winter where there is a scarcity of adequate pasture (TOKARNIA et al., 2002), as occurred during this study.

In conclusion, the results of this investigation have demonstrated that multifactorial circumstances are fundamental for the development and maintenance of disease in livestock. Although multifactorial conditions are discussed in classroom as being the principal cause of disease in domestic animals, this is not frequently demonstrated. However, during this investigation, the winter conditions of southern
Brazil hinder the development of adequate pasture. Since most Brazilian cattle are raised on grasslands, the absence of adequate foodstuffaltered the selective capacity of the affected animals. The prolonged ingestion of mycotoxin-contaminated silage might have predisposed the cattle to BVDV infection, which further depressed the immunological system of these animals so that they were more susceptible to pulmonary and other viral diseases.

\section{Acknowledgements}

The authors are grateful to Dr. Antônio Laércio Sversuti for the invitation to assist in the understanding and resolving of the mortality at this farm. Drs. S. A. Headley, A. F. Alfieri, J. A. N. Lisbôa, and A. A. Alfieri are recipients of the National Council for Scientific and Technological Development (CNPq; Brazil) fellowships. This study was partially funded by a joint $\mathrm{CNPq} / \mathrm{Ministry}$ of Agriculture, Livestock, and Supply (MAPA) grant (Protocol \#578645/2008-4).

\section{References}

ALEXANDRINO, B.; DIAS, F. C.; OLIVEIRA, M. C.; AFFONSO, I. B.; PEREIRA, G. T.; SAMARA, S. I. Infectious bovine rinotracheitis associated with bovine viral diarrhea and enzootic bovine leucosis. Ars Veterinaria, Jaboticabal, v. 27, n. 3, p. 168-174, 2011.

ALFIERI, A. A.; PARAZZI, M. E.; TAKIUCHI, E.; MEDICI, K. C.; ALFIERI, A. F. Frequency of group A rotavirus in diarrhoeic calves in Brazilian cattle herds, 1998-2002. Tropical Animal Health and Production, London, v. 38, n. 7-8, p. 521-526, 2006.

BATTACONE, G.; NUDDA, A.; PULINA, G. Effects of ochratoxin a on livestock production. Toxins, Basel, v. 2, n. 7, p. 1796-1824, 2010.

BROWN, C. C.; BAKER, D. C.; BARKER, K. Alimentary system. In: MAXIE, M. G. (Ed.). Jubb, Kennedy, and Palmer's Pathology of Domestic Animals. Philadelphia: Saunders/Elsevier, v. 2, 2007. cap. 1, p. 3-296.

CAMPOS, F. S.; FRANCO, A. C.; HUBNER, S. O.; OLIVEIRA, M. T.; SILVA, A. D.; ESTEVES, P. A.; ROEHE, P. M.; RIJSEWIJK, F. A. High prevalence of 
co-infections with bovine herpesvirus 1 and 5 found in cattle in southern Brazil. Veterinary Microbiology, Amsterdam, v. 139, n. 1-2, p. 67-73, 2009.

CLAUS, M. P.; ALFIERI, A. F.; FOLGUERASFLATSCHART, A. V.; WOSIACKI, S. R.; MEDICI, K. C.; ALFIERI, A. A. Rapid detection and differentiation of bovine herpesvirus 1 and 5 glycoprotein $\mathrm{C}$ gene in clinical specimens by multiplex-PCR. Journal of Virological Methods, London, v. 128, n. 1-2, p. 183-188, 2005.

CORTEZ, A.; HEINEMANN, M. B.; CASTRO, A. M. M. G. D.; SOARES, R. M.; PINTO, A. M. V.; ALFIERI, A. A.; FLORES, E. F.; LEITE, R. C.; RICHTZENHAIN, L. J. Genetic characterization of Brazilian bovine viral diarrhea virus isolates by partial nucleotide sequencing of the 5'-UTR region. Pesquisa Veterinária Brasileira, Rio de Janeiro, v. 26, n. 4, p. 211-216, 2006.

DIAS, F. C.; MÉDICI, K. C.; ALEXANDRINO, B.; MEDEIROS, A. S. R.; ALFIERI, A. A.; SAMARA, S. I. Occurrence of persistently infected animals with bovine viral diarrhoea virus in cattle herds from the States of Minas Gerais and São Paulo, Brazil. Pesquisa Veterinária Brasileira, Rio de Janeiro, v. 30, n. 11, p. 933-939, 2010.

FLORES, E. F.; WEIBLEN, R.; VOGEL, F. S. F.; ROEHE, P. M.; ALFIERI, A. A.; PITUCO, E. M. A infecção pelo vírus da diarréia viral bovina (BVDV) no Brasil: histórico, situação atual e perspectivas. Pesquisa Veterinária Brasileira, Rio de Janeiro, v. 25, p. 125-134, 2005.

GALEY, F. D. Disease caused by toxicants. In: SMITH, B. P. (Ed.). Large animal internal medicine. $4^{\text {th }}$ ed. St. Louis, Missouri: Mosby/Elsevier, 2009. cap. 54, p. 16911719.

HANAA, A. G.; NAGLAA, I. H.; HANAA, A. E.; NABIH, A. M. Mixed infection of bovine viral diarrhea virus, Mycoplasma species and Mannheimia haemolytica in calves showed chronic pneumonia with reference to the histopathological findings of the affected lungs. Journal of American Science, East Lansing, v. 6, p. 538$555,2010$.

HEADLEY, S. A.; GILLEN, M. A.; SANCHES, A. W.; SATTI, M. Z. Platynosomum fastosum-induced chronic intrahepatic cholangitis and Spirometra spp. infections in feral cats from Grand Cayman. Journal of Helminthology, London, v. 86, n. 2, p. 209-214, 2012.

HEADLEY, S. A.; VOLTARELLI, D.; OLIVEIRA, V. H. S.; BRONKHORST, D. E.; ALFIERI, A. F.; NEGRI, L. C.; OKANO, W.; ALFIERI, A. A. Association of Histophilus somni with spontaneous abortions in dairy cattle herds from Brazil. Tropical Animal Health and Production, London, v. Accepted, 2014.
HEADLEY, S. A.; SAUT, J. P. E.; GOMES, D. A.; SILVA, D. R. M.; ALMEIDA, I. A.; SANGIONI, L.A. Simultaneous chronic seneciosis and eurytrematosis in a cow. Semina Ciências Agrárias, Londrina, v. 25, n. 2, p. 131-138, 2004.

HOUE, H. Epidemiological features and economical importance of bovine virus diarrhoea virus (BVDV) infections. Veterinary Microbiology, Amsterdam, v. 64, n. 2-3, p. 89-107, 1999.

KING, A. M. Q.; LEFKOWITZ, E.; ADAMS, M. J.; CARSTENS, E. B. Family - flaviviridae. In: KING, A. M. Q.; LEFKOWITZ, E. et al. (Ed.). Virus taxonomy. ninth report of the international committee for the taxonomy of viruses. New York: Elsevier, 2011. p. 1003-1020.

LUNARDI, M.; HEADLEY, S. A.; LISBOA, J. A.; AMUDE, A. M.;ALFIERI, A. A. Outbreak of acute bovine viral diarrhea in Brazilian beef cattle: clinicopathological findings and molecular characterization of a wild-type BVDV strain subtype 1b. Research in Veterinary Science, London, v. 85, n. 3, p. 599-604, 2008.

MACLACHLAN, N. J.; DUBOVI, E. J. Bovine viral diarrhea virus. $4^{\text {th }}$ ed. San Diego: Academic Press, 2011. 475-479.

MÉDICI, K. C.; ALFIERI, A. A.; ALFIERI, A. F. Prevalência de anticorpos neutralizantes contra o herpesvírus bovino tipo 1, decorrente de infecção natural, em rebanhos com distúrbios reprodutivos Ciência Rural, Santa Maria, v. 30, n. 2, p. 347-350, 2000.

MORE, G.; BASSO, W.; BACIGALUPE, D.; VENTURINI, M. C.; VENTURINI, L. Diagnosis of Sarcocystis cruzi, Neospora caninum, and Toxoplasma gondii infections in cattle. Parasitology Research, Berlin, v. 102, n. 4, p. 671-675, 2008.

MOSTROM, M. S.; JACOBSEN, B. J. Ruminant mycotoxicosis. The Veterinary Clinics of North America. Food Animal Practice, Philadelphia, v. 27, n. 2, p. 315344, 2011.

OSWALD, I. P.; MARIN, D. E.; BOUHET, S.; PINTON, P.; TARANU, I.; ACCENSI, F. Immunotoxicological risk of mycotoxins for domestic animals. Food Additives and Contaminants, London, v. 22, n. 4, p. 354-360, 2005.

OTONEL, R. A. A.; ALFIERI, A. F.; DEZEN, S.; LUNARDI, M.; HEADLEY, S. A.; ALFIERI, A. A. The diversity of BVDV subgenotypes in a vaccinated dairy herd. Tropical Animal Health and Production, London, v. 46, n. 1, p. 87-92, 2014.

RICHER, L.; MAROIS, P.; LAMONTAGNE, L. Association of bovine viral diarrhea virus with multiple viral infections in bovine respiratory disease outbreaks. Canadian Veterinary Journal, Ottawa, v. 29, n. 9, p. 713717, 1988. 
RIET-CORREA, F.; MEDEIROS, R. M. T. Intoxicações por plantas em ruminantes no Brasil e no Uruguai: importância econômica, controle e riscos para a saúde pública. Pesquisa Veterinária Brasileira, Rio de Janeiro, v. 21, n. 1, p. 38-42, 2001.

SANTOS, S. L.; DE SOUZA COSTA, K.; GONDIM, L. Q.; DA SILVA, M. S.; UZEDA, R. S.; ABE-SANDES, K.; GONDIM, L. F. Investigation of Neospora caninum, Hammondia sp., and Toxoplasma gondii in tissues from slaughtered beef cattle in Bahia, Brazil. Parasitology Research, Berlin, v. 106, n. 2, p. 457-461, 2010.

SLEDGE, D. G.; MAES, R.; WISE, A.; KIUPEL, M.; FITZGERALD, S. D. Coinfection of a cow with bovine leukemia virus and Mycobacterium bovis. Journal of Veterinary Diagnostic Investigation, Columbia, v. 21, n. 6, p. 878-882, 2009.

SPILKI, F. R.; SILVA, T. C.; ESTEVESM, P. A.; TEIXEIRA, M. B.; BATISTA, H. B. C. R.; CHIMINAZZO, C.; DRIEMEIER, D.; FRANCO, A. C.; ROEHE, P. M. Co-infections with bovine herpesvirus type 5 and bovine viral diarrhoea virus. Arquivo Brasileiro de Medicina Veterinária e Zootecnia, Belo Horizonte, v. 58, n. 5, p. 699-707, 2006.
STALKER, M. G.; HAYES, M. A. Liver and biliary system. In: MAXIE, M. G. (Ed.). Jubb, Kennedy, and Palmer's Pathology of Domestic Animals. 5th. Philadelphia: Saunders/Elsevier, v. 2, 2007. cap. 2, p. 297-388.

TAMURA, K.; PETERSON, D.; PETERSON, N.; STECHER, G.; NEI, M.; KUMAR, S. MEGA5: molecular evolutionary genetics analysis using maximum likelihood, evolutionary distance, and maximum parsimony methods. Molecular Biology and Evolution, Chicago, v. 28, n. 10, p. 2731-2739, 2011.

TOKARNIA, C. H.; DOBEREINER, J.; PEIXOTO, P. V. Poisonous plants affecting livestock in Brazil. Toxicon, Elmsford, v. 40, n. 12, p. 1635-1660, 2002.

UPADHAYA, S. D.; PARK, M. A.; HA, J. K. Mycotoxins and their biotransformation in the rumen: a review. AsianAustralasian Journal of Animal Sciences, Suweon, v. 23, n. 9, p. 1250-1260, 2010.

VILČEK, ̌̌.; HERRING, A. J.; HERRING, J. A.; NETTleton, P. F.; LOWINGS, J. P.; PATON, D. J. Pestiviruses isolated from pigs, cattle and sheep can be allocated into at least three genogroups using polymerase chain reaction and restriction endonuclease analysis. Archives of Virology, New York, v. 136, n. 3, p. 309-323, 1994. 
